\title{
EFFECT OF TRANSPLANTING ON APICAL DEVELOPMENT OF RICE VARIETY AT 85-2
}

\author{
N. SENANAYAKE AND M.T.M. DAYANI R.PERERA \\ Regional Agricultural Research Centre, Angunukolapalessa.
}

(Received : 05 November 1993 ; accepted : 23 June 1994)

\begin{abstract}
Experiments were conducted in the greenhouse at the Regional Agricultural Research Station, Angunukolapalessa, to study the physiological and morphological changes in apical development of rice under broadcast sown and transplanted conditions. Results show that transplanting shock increases the differentiation of leaf primordia, but not the physiological development stage. Thus increased rice yields under transplanted conditions can be attributed to increased leaf area which enhances assimilation with a favourable sink-source relationship. However pre-and post-spikelet abortion was observed under both transplanted and broadcast sown conditions even though the rate is higher in broadcast sowing.
\end{abstract}

Key words: N - management, panicle initiation, spikelet abortion.

\section{INTRODUCTION}

Apical development of lowland rice is more complex than that of temperate cereals. Patterns of development differ between rice varieties and are modified by the environment. ${ }^{1}$ Apical development can be broadly divided into vegetative, reproductive and maturity phases. The reproductive and maturity phases are relatively constant, irrespective of variety and take about $23-25 \mathrm{~d}$ and $30-35 \mathrm{~d}$ respectively. ${ }^{2,3}$ However, rice varieties differ in their growth duration from sowing to grain maturity as a result of an extension of the vegetative growth period $^{2,4}$ which is short in early varieties and long in late duration varieties.

Hitherto guidelines for cultural management of the rice crops have been based on calendar dates with adjustment for the growth duration of the variety. Numerous developmental indices have been proposed but all have limitations. ${ }^{6-10}$ This is because the apical development stages, at which cultural management decisions are necessary, are not obviously or consistently indicated by external morphology. Transplanting in rice also causes an extension of growth duration by $10-14 \mathrm{~d}^{2,3}$ Thus, agronomic practices need to be adjusted accordingly to obtain higher rice yields. Senanayake et al. ${ }^{11}$ have developed and documented an appropriate scale to identify different apical development stages of rice from the Zadoks ${ }^{12}$ growth scale for temperate cereals and pointed to the importance of preflowering and post-flowering abortion of spikelets in determining yield under broadcast sown conditions. However the effect of transplanting on this scale has not been studied . Relationship of apical development to external morphology was constant in a particular variety but the change in space of these stages due to transplanting shock and its relationship to external morphology under transplanted conditions were not documented. We report here on the apical 
development of rice under transplanted conditions compared with broadcast sowing and on the effects on growth stages as a result of transplanting shock.

\section{METHODS AND MATERIALS}

Greenhouse experiments were conducted at the Regional Agricultural Research Station, Angunukolapalessa during Yala 1992 and Maha 1992/93. Rice Variety At 85-2 which has a growth duration of 105 d was used.

Seeds were soaked for $24 \mathrm{~h}$, incubated for $48 \mathrm{~h}$ and nursery sown in trays containing lowland soil. After eighteen days vigorous plants were selected and planted, in plastic pots $\left(0.3 \mathrm{~m}^{2}\right)$, containing the moist equivalent of $10 \mathrm{~kg}$ oven dried soil (Low Humic Gley soils). Eight plants per pot was transplanted to simulate field planting at $15 \times 20 \mathrm{~cm}$ spacing (2-3 plants per hill). Twenty pots were transplanted and an equal number of pots were broadcast sown at the rate of $50 \mathrm{Kg}$ seeds /ha and at the same time as the nursery sowing. Pots were irrigated to have 1 inch standing water always and fertilized with 100:25:20 kg $\mathrm{N}: \mathrm{P}: \mathrm{K} / \mathrm{ha} ; 30 \mathrm{Kg} \mathrm{N}$ and all $\mathrm{P}$ and $\mathrm{K}$ were applied at transplanting/sowing. The remaining $70 \mathrm{Kg} \mathrm{N}$ was applied $35 \mathrm{~d}$ after in transplanted treatment and $42 \mathrm{~d}$ after in broadcast sown treatment. ${ }^{13}$ Pots were arranged in RCB design inside the greenhouse and minimized the shading effect.

For each treatment, plant samples were taken by selecting random plants (10 plants, one plant each from every other pot in every other sampling) from different pots. Sampling were done once a week during the vegetative stage and at maturity, but 2-3 times a week during the reproductive stage. An initial sample of 10 plants was reduced to a modal sample of 6 plants by discarding the two biggest and two smallest plants. The apical development stage was identified under a low power dissecting microscope, using the technique of Kirby and Appleyard ${ }^{14}$ and by reference to rice development stages. The number of differentiated primordia were counted at each sampling under low power dissecting microscope.

\section{RESULTS AND DISCUSSION}

The results of two experiments are shown in the Table 1 . These indicate that the major physiological development stages of the plant do not change appreciably on transplantation. Physiological panicle initiation was observed between 37 to $45 \mathrm{~d}$ after sowing and maximum spikelet number stage was observed between 60 to $63 \mathrm{~d}$ after sowing under both treatments. Further the development trend under these two stand establishment methods followed the same trend (Fig. 1). However transplanting shock increased the leaf primordia differentiation during both seasons and a higher number of leaves are produced increasing the leaf area index. Therefore sink -source relationship was improved under transplanting, as a result of which the total number of primordia differentiated under transplanting was increased. At maximum spikelet number stage of the rice plant, $50-100 \%$ increase in total differentiated primordia was observed in the 
two experiments. However more than $50 \%$ of the differentiated spikelet primordia abort under both establishment methods in two stages; pre-and post-flowering abortion (Fig. 1). Senanayake et al. ${ }^{11}$ also observed similar results under broadcast sown conditions. This trend in spikelet abortion in rice needs to be further studied to increase potential rice yields.

Rice can be established in the field by several methods. Most common method of stand establishment is broadcast sowing. Transplanting which needs lot of labour has very little applicability in Sri Lanka. Transplanting is done at the seedling age between 18-21d below which the plants are too small to hanale and above 18-21d the plants approach sensitive panicle initiation stage. Rice scientists ${ }^{2,3}$ have indicated that transplanting delays maturity due to transplanting shock but results in higher yields. ${ }^{3}$ This was attributed to uniform spacing given to the plants whereby rice plant can produce more tillers, and also uniform tillering. Under broadcast sowing different plants will have different opportunities to produce tillers because of uneven sowing. ${ }^{2,3}$

The tendency of the rice plant to produce more leaf primordia could probably be an adaptive mechanism. Since the existing foliage of the rice plants were trimmed to prevent uprooting by winds after transplanting, the shoot apex was probably stimulated to differentiate in to more leaf primordia.

Earlier experiments also showed clearly that greater numbers of tillers are produced and therefore more panicles per square meter under transplanted conditions. ${ }^{2,3}$ Increased yields under transplanted conditions can then be attributed to two reasons viz. the increased tiller number ${ }^{2,3}$ and the improved sinksource relationship.

Data also suggest that the total number of leaves produced vary between seasons which can be attributed to the severity of the transplanting shock and the micro-climatic differences observed between seasons (cumulative maximum temperature sum during vegetative stage of rice inside the greenhouse was $1044.7^{\circ} \mathrm{C}$ for the wet season and $1237.9^{\circ} \mathrm{C}$ for the dry season).

Cumulative pre-and post-flowering spikelet abortion is also greater under broadcast sowing (69-79\%) compared to transplanting (54-69\%). This can be attributed to fewer leaves resulting in lower assimilation and a limited source to sustain the differentiated spikelets. As a result, greater pre -flowering abortion was observed in both seasons under broadcast sowing. On transplanting, the larger number of leaves produced results in higher assimilation to sustain the differentiated spikelets. 


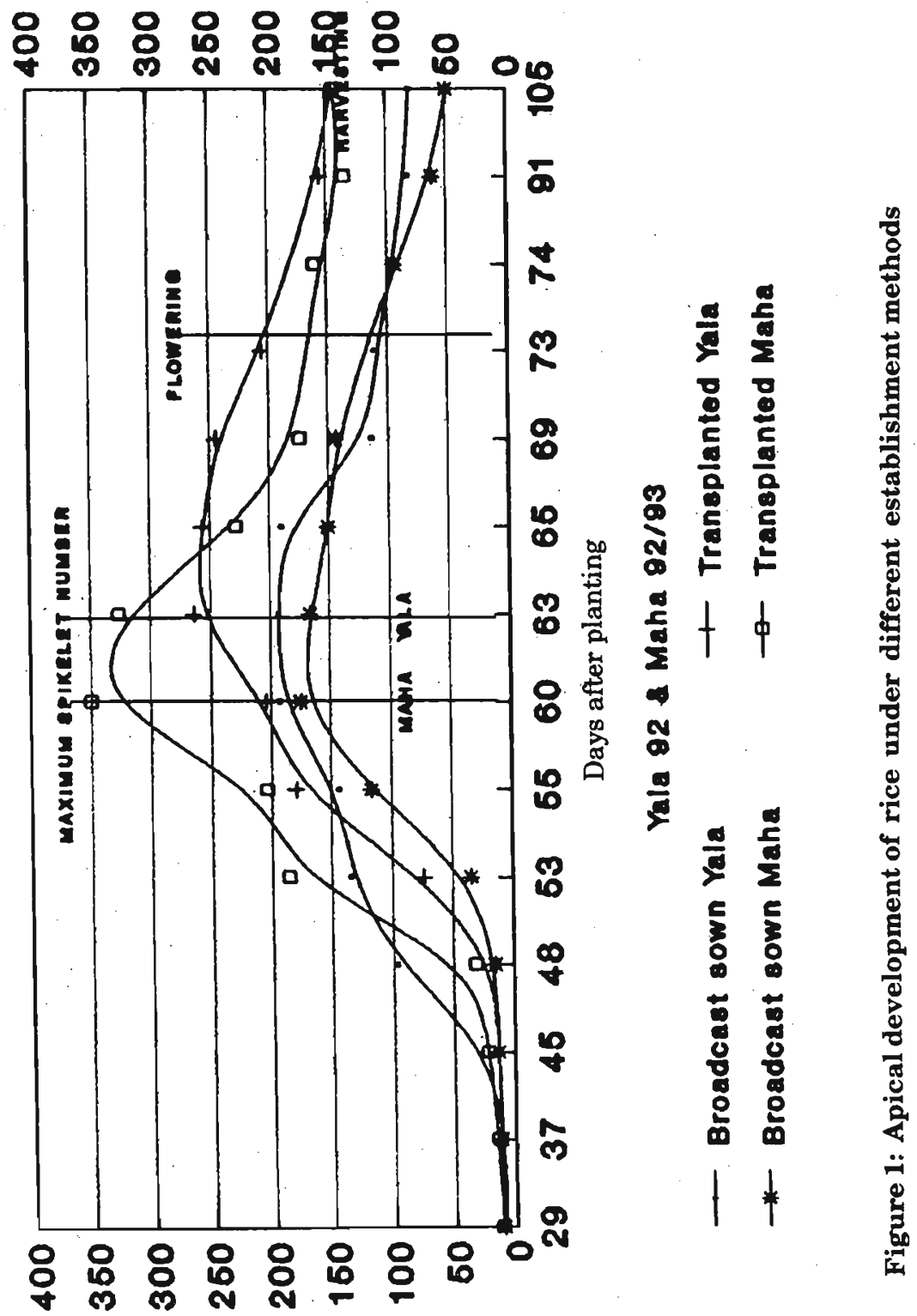

e!p.ourud jo səquinu [e70L 
Table 1 : Apical development and leaf primordia production under different establishment methods and seasons in greenhouse (max. Temp.35$36^{\circ} \mathrm{C}$ ) pot experiments.

\begin{tabular}{|c|c|c|c|c|c|}
\hline \multirow[t]{3}{*}{ DAS* } & \multicolumn{4}{|c|}{ No. of leaves } & \multirow{3}{*}{$\begin{array}{l}\text { Development } \\
\text { Stage }\end{array}$} \\
\hline & \multicolumn{2}{|c|}{ Yala (Dry) 1992} & \multicolumn{2}{|c|}{ Maha (Wet) 1992/93 } & \\
\hline & $\begin{array}{l}\text { Broadcast } \\
\text { sown }\end{array}$ & $\begin{array}{l}\text { Trans- } \\
\text { planted }\end{array}$ & $\begin{array}{l}\text { Broadcast } \\
\text { sown }\end{array}$ & $\begin{array}{l}\text { Trans- } \\
\text { planted }\end{array}$ & \\
\hline 5 & 1.0 & 1.0 & 2.0 & 2.0 & \\
\hline 11 & 2.0 & 2.0 & - & - & \\
\hline 15 & - & - & 3.5 & 3.5 & \\
\hline 19 & 3.0 & 3.0 & 4.0 & 4.0 & \\
\hline 22 & 3.0 & 3.0 & 4.6 & 5.0 & TPL \\
\hline 29 & 4.0 & 7.0 & 5.7 & 6.0 & \\
\hline 37 & 5.0 & 8.3 & 7.0 & 8.0 & \\
\hline 45 & 7.8 & 10.0 & 8.0 & 9.8 & \\
\hline 48 & 8.6 & 10.5 & 8.3 & 10.0 & \\
\hline 53 & 9.1 & 11.0 & 9.0 & 12.6 & PI \\
\hline 55 & 9.2 & 11.0 & 9.0 & 12.6 & \\
\hline 60 & 10.0 & 11.0 & 10.2 & 12.6 & \\
\hline 63 & 10.0 & 12.0 & 10.2 & 12.2 & \\
\hline 65 & 10.0 & 12.3 & 10.8 & 13.6 & MSN \\
\hline 69 & 10.0 & 13.0 & 11.8 & 13.4 & \\
\hline 73 & 10.0 & 13.0 & 11.8 & 13.8 & Flowering \\
\hline 91 & 10.0 & 13.0 & 11.0 & 13.6 & \\
\hline 105 & 10.0 & 13.0 & 11.0 & 14.0 & Harvesting \\
\hline
\end{tabular}

Abbreviations: DAS - Days after planting, TPL - Transplanting, PI - Panicle Initiation, MSN - Maximum Spikelet Number.

Transplanting normally delays maturity by $10-14 \mathrm{~d}^{2,3}$ However in greenhouse pot experiments where the soil environment is limited and temperatures are high, maturity can be enhanced. In these two experiments there were no appreciable differences in the number of days taken to reach maturity probably because the experiments were conducted under greenhouse conditions in pots.

\section{References}

1. Tanaka A., Navasero S.A., Garcia G.V., Parao P.T. \& Ramirez E. (1964). Growth Habit of the rice plant in the tropics and its effect on $\mathrm{N}$ response, IRRI, Technical Bulletin, No 3.

2. Yoshida S. (1981). Fundamentals of rice crop science, International Rice Research Institute, Los Banos, Philippines. 
3. De Datta S.K. (1981). Principles and practices of rice production. John Wiley and Sons, New York: 618 pp.

4. Vergara B.S. \& Chang T.T. (1985). Flowering response of rice plants to photoperiodism, review of literature, (4th ed.). IRRI, Los Banos, Philippines.

5. Akimoto S.\& Togari. Y (1939). Varietal differences in panicle development of rice with reference to early and late transplanting. Proceedingsof the Crop Science Society of Japan 11: 168-184.

6. Hall V.L., Sims S.M., \& Johnston T.H. (1968). Timing of N fertilization of rice II. Culm elongation as a guide optimum timing of application near mid season. Agronomy Journal 60: 450 - 455.

7. Ling C.H., Cai Z.J., \& Sou S.P. (1980). The practical value of using the leaf index and leaf remainder in determining the stages of panicle differentiation of the rice plant. Scientific Agriculture Sinica 14: 1-11.

8. Matsushima S. (1961). Theory and technique of rice cultivation, determination of yield and its application. Dept. of Agriculture, Kuala Lumpur, Malaysia.

9. Matsushima S. \& Manaka T. (1957). Developmental process of the young panicle of rice and its identification. (In Japanese, English summary). Nogyo, Gjutsu, Kyokai.

10. Ming Hwa Ling (1974). Studies on the relation among the leaf age index the stage of panicle development and number of tillers in rice. Journal of Taiwan Agricultural Research 23(3): 175-186.

11. Senanayake. N., De Datta S.K., Naylor R.E.L. \& Thomson W.J. (1991). Lowland rice apical development : stages and cultivar differences detected by electron microscopy. Agronomy Journal 83: 1013-1023.

12. Zadoks J.C., Chang T.T. \& Konzac C.F. (1974). A decimal code for the growth stages of cereals. Weed Research 14: 415-421.

13. Department of Agriculture (1990). Fertilizer recommendations for rice. Extension Division, Department of Agriculture, Sri Lanka.

14. Kirby E.J.M. \& Appleyard M. (1984). Cereal Development Guide, (2nd ed.) Arable Unit, National Agricultural Centre, Stoneleigh, Kenilworth, War wickshire, U.K. 